\title{
Customer Loyalty Management System Development for Auto 4S Dealers Based on Intelligent Mobile Terminal
}

\author{
Li Yuansheng ${ }^{1}$ Cui Liangyi ${ }^{1}$ Xu Xiangyang ${ }^{1}$ \\ ${ }^{1}$ School of Transportation Science \& Engineering, Beihang University
}

\begin{abstract}
With brand sales \& service model used by Auto $4 \mathrm{~S}$ dealers being the mainstream of automobile dealing network in China, customer loyalty management and improvement has become the core competiveness of companies in automobile after-sales-market. This paper combines the intelligent mobile terminal which helps improve customer satisfaction and loyalty with cloud service and summarizes the key factors affecting customer satisfaction and loyalty with reference to foreign achievements. An APP of customer loyalty management system for $4 \mathrm{~S}$ dealers is developed as an intelligent mobile tool M4S (Mobile for Service, or Mobile 4S) for the communication between $4 \mathrm{~S}$ dealers and their customers.
\end{abstract}

Keywords: Auto 4S dealers, Customer Loyalty, Intelligent Mobile Terminal, APP

\section{Overview}

In 1999, Guangzhou Honda introduced a new brand sales \& service model known as " $4 S$ " to China. Since then, this model has soon become the mainstream of automobile dealing network in China. As the competition in automobile after-salesmarket becomes fiercer, it emerges as a key challenge of how to improve customer loyalty ${ }^{[1]}$.

With the rapid development of computer technology, communication technology, smart phone technology and Internet of things, using devices such as computers, the Internet and smart phones in the management of customer information and communication has become a new way of communication and make it possible for everyone to share the skills of talents and provide good service which used to be available from specific staff. This provides new opportunities for development in automobile service market, thus makes it a core issue in the market research of how to make use of new technologies and develop new business service mode to improve customer satisfaction and loyalty. In this context, this paper proposes a brand new idea of improving customer satisfaction --- M4S (Mobile for Service, or Mobile 4S). It is a new model based on mobile network of automobile service and serves as an intelligent management tool for customer satisfaction and loyalty improvement.

\section{Customer \& Company Require- ments in the New Age}

1) Customer characteristics:

The only child has become the major consumptive power in society. Their sense of staying in the center of the spot- 
light, inner loneliness and selfishness give rise to a lack of concern about prices. They are mostly self-centered and willing to spend money beforehand on new products for pleasure.

2) Fragmented time:

Modern people are facing high pressure in their life and career and their time is limited and precious. More often than not, they have to use pieces of leisure time to obtain some non-job-related knowledge. These pieces of time are the so-called fragmented time. It should be the main concern for modern companies' marketing departments of how to appropriately make use of the fragmented time of the society's backbones.

3) Active participation and interactive communication:

We found after researches that the decisive factor in customers' ordering and purchasing behavior is the ratification and recommendation of their families and friends ${ }^{[2]}$.However most customers hold a skeptical attitude towards dealers' active marketing or even resist it. What customers really demand is the initiative of communication, which is equal, effective and purpose-oriented.

4) $4 \mathrm{~S}$ dealers aspire to more opportunities to provide value-added service:

The effective communication initiated by the actual demands of customers can help facilitate the deal with potential customers, thus increase the achievement rate of sales [3]. Customers' expanding knowledge of automobiles and $4 \mathrm{~S}$ dealers and their recommendation to families and friends are the most powerful advertisement for marketing. The referral rate automatically increases when minimal investment creates effective value as soon as possible. Meanwhile, customers are kept from the disturbance of commercial advertising. Their sense of approval and belonging will automatically lead them back to $4 \mathrm{~S}$ dealers for more service, which accordingly improve customer return rate.

\section{Introduction to the System}

M4S (Mobile for Service, of Mobile 4S) is an overall solution to the cultivation of customer loyalty based on an insightful research on the automobile after-salesmarket in the past 30 years. We draw lessons from the foreign service mode and management experience, integrate multiple service modes in the automobile after-sales-market industrial chain, follow the rules of customer service satisfaction (CSS) and customer loyalty (CL), conduct market surveys on over ten thousands vehicle owners according to their driving habits and consumption habits before finally summarizing the key factors in improving customer satisfaction and loyalty. It helps automobile service providers to satisfy customer demands during the whole automobile service life using the most advanced cloud service platform and mobile intelligent terminal. The advanced intelligent tool M4S system for customer satisfaction improvement is developed for the purpose of helping $4 \mathrm{~S}$ dealers with their market promotion and customer care which is cost-effective and controllable through Internet applications.

M4S APP is installed in vehicle owner's mobile phone and serves as a tool for $4 \mathrm{~S}$ dealers to provide overall process services. On the one hand, $4 \mathrm{~S}$ dealers increase customer satisfaction and sense of belonging through considerate but non-forced guidance and service for customers, thus gain more business opportunities; on the other hand, vehicle owners enjoy prominent services through the software platform. 


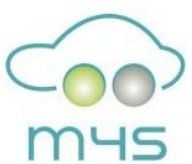

Fig. 1: M4S icon

Double click the desktop icon showed in figure 1 and enter the system, see figure 2. At this moment, you can make emergency phone calls even at the absence of data communication service. After entering the system, the first function you see is "the to-do-list reminder".

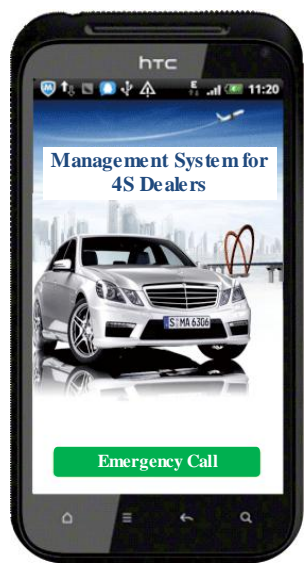

Fig. 2: M4S system page

M4S APP provides five main function modules for vehicle owners: Query, Service, SOS Emergency Calls, Information and Complaint. Table 1 shows the function distribution of each module.

Among the 36 modules, 22 of them are directly related to $4 \mathrm{~S}$ business and defined by $4 \mathrm{~S}$ dealers; 11 of the rest 14 modules are designed to improve local customer viscosity and defined by AMIS local organizations since they require localized service, the other 3 modules receive public automobile knowledge and magazines as well as system notifications provided by AMIS headquarter.
Table 1: Five main function modules

\begin{tabular}{|c|c|}
\hline Function & Function module \\
\hline \multicolumn{2}{|l|}{$\begin{array}{l}\text { Latest In- } \\
\text { formation }\end{array}$} \\
\hline 1 & Information for new cars \\
\hline 2 & $\begin{array}{l}\text { Information for sales } \\
\text { events }\end{array}$ \\
\hline 3 & Information for service \\
\hline 4 & $\begin{array}{l}\text { Information for traffic } \\
\text { violations }\end{array}$ \\
\hline 5 & $\begin{array}{l}\text { Information for high- } \\
\text { speed railways }\end{array}$ \\
\hline 6 & $\begin{array}{l}\text { Warning of traffic- } \\
\text { violation-prone area }\end{array}$ \\
\hline 7 & $\begin{array}{l}\text { Information of the vehi- } \\
\text { cle }\end{array}$ \\
\hline 8 & $\begin{array}{l}\text { Participation of car-pal- } \\
\text { events }\end{array}$ \\
\hline 9 & Information of the price \\
\hline 10 & $\begin{array}{l}\text { Information of car acci- } \\
\text { dent insurance }\end{array}$ \\
\hline \multicolumn{2}{|l|}{$\begin{array}{l}\text { Online ser- } \\
\text { vice }\end{array}$} \\
\hline 11 & Test driving appointment \\
\hline 12 & Automobile finance \\
\hline 13 & Insurance purchase \\
\hline 14 & $\begin{array}{l}\text { Maintenance service res- } \\
\text { ervation }\end{array}$ \\
\hline 15 & Scratch troubleshooting \\
\hline 16 & Car renting \\
\hline 17 & Second-hand cars \\
\hline 18 & Annual check \\
\hline 19 & $\begin{array}{l}\text { Clearing up traffic viola- } \\
\text { tion records }\end{array}$ \\
\hline 20 & Recommendation \\
\hline 21 & $\begin{array}{l}\text { New driver accompany- } \\
\text { ing and training }\end{array}$ \\
\hline 22 & $\begin{array}{l}\text { Driving service for } \\
\text { drinking car pal }\end{array}$ \\
\hline \multicolumn{2}{|l|}{$\begin{array}{l}\text { Car-pal in- } \\
\text { teraction }\end{array}$} \\
\hline 23 & Intranet messages \\
\hline 24 & Interest magazines \\
\hline 25 & $\begin{array}{l}\text { Automobile knowledge } \\
\text { base }\end{array}$ \\
\hline
\end{tabular}




\begin{tabular}{|l|l|}
\hline 26 & Revisit and survey \\
\hline 27 & Customer complaints \\
\hline 28 & $\begin{array}{l}\text { Owners sharing experi- } \\
\text { ence }\end{array}$ \\
\hline 29 & A bite of the city \\
\hline 30 & The nightlife of the city \\
\hline 31 & City tour \\
\hline 32 & Fashion \\
\hline 33 & Tour around China \\
\hline 34 & User's guidance \\
\hline $\begin{array}{l}\text { Emergency } \\
\text { calls }\end{array}$ & \\
\hline 35 & SOS emergency calls \\
\hline $\begin{array}{l}\text { Consultant } \\
\text { reminder }\end{array}$ & \\
\hline 36 & Sales consultant \\
\hline & Service advisor \\
\hline & Customer service \\
\hline
\end{tabular}

\section{Implementation and Layout of M4S}

M4S adopts the cloud service + targeted service of intelligent terminal application. Its implementation and layout are carried out on the back-stage and does not affect $4 \mathrm{~S}$ business. What's more, the installation is easy and customer-oriented and the whole process is quite smooth.

$4 \mathrm{~S}$ application involves the following three layers: the front operating layer of sales consultant, service advisor and customer service; the manager analyzing layer; the back-stage information managing layer. A cluster of cloud servers which allows tens of millions of users to be online at the same time can be built to guarantee an unblocked national network of data and communication.

M4S system adopts cloud service and conducts unified management of the physical and virtual resources in the cloud service resource pool throughout the entire network, thus achieves the cloud computing economies of scale; it also strengthens the data security management, establishes a mechanism of data access control, data redundancy backup and disaster recovery, increases the monitoring, measuring, analyzing and statistical ability over the usage of cloud service resources, and provides service reports based on SLA to customers.

\subsection{S Application Deployment}

The $4 \mathrm{~S}$ back-stage data management port can be set at any Internet-accessible computer within the company. This port is where all the basic data settings are completed, including the project title, pictures for system implementation page, company's logo, phone numbers of emergency calls, staff information, customer information input, matching of the customer and the staff, work arrangement for the staff, periodical table for changing unconventional consumables of company's brand cars , price list of conventional services and accessories, data base of the driving \& riding experience of self-owned brand cars, automobile maintenance services, parts that require frequent check and change upon the company's request, examination and approval of experience shared by vehicle owners and feedback and information forwarding of customer complaints as an assist for the management layer, etc.

The system, serving as a communication supporting platform for business systems, allows flexible settings to accommodate different companies' operating habits.

The management layer mainly deals with customer complaints and data analysis as well as automatic deployment. The organization system involves the business training and testing for the frontlayer consultants.

Front-layer consultants can provide service to customers through $24 \mathrm{~h}$ Internet-available mobile phone, but 
cannot make phone calls to customers in order to keep them from disturbance.

WIFI should be available in customer service lobby and the staff workplace in order to save network traffic for customers and staff.

\subsection{Customer Application Promotion}

Set QR mode: set the M4S download link as QR mode and print it or put it on media, websites, business cards, exhibitions, showrooms, brochures, event flags, demo cars and so on, so that customers can download the app by taking a photo of the QR code and install the system in their mobile phones, see figure 4 .

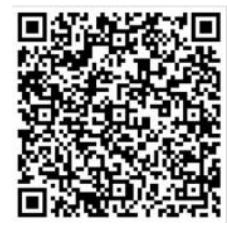

Fig. 4: QR code

Besides QR code, other methods can also be used to promote installation of the app: sending text message link; Bluetooth link; marketing through companies' microblog; sending download link in QQ groups; inviting media to report on the new app for customer service and care improvement; service advisors assisting old customers to bind mobile settings with license plate thus realize "trinity" between automobile, mobile phone and customer himself; virus-cross-infectionlike pyramid marketing, etc.

\section{Conclusion}

M4S system provides a communication platform for $4 \mathrm{~S}$ dealers and vehicle owners based on owners' actual demand, increases the efficiency of customer service response, turns a one-way-mode of customer calling for service into a double-way-mode of interactive communication, and serves as a customer-collecting tool which is new, practical and customer-oriented in the automobile after-sales-market. M4S is an innovative M2C (Mobile to Customer) mode which uses mobile network to facilitate value-added service for conventional business as well as handy online promotion and timely communication. It does not only help vehicle owners to get service and increase their customer loyalty, but also improves the $4 \mathrm{~S}$ service quality, their competitiveness and profitability.

\section{References}

[1] Li Huali, "War for Customers - 49 Details That Help Improve Customer Loyalty", China Development Press, 2010

[2] Yoshitake Suwa, "Service Matters", Enterprise Management Publishing House, 2011

[3] Takeda Tetsuo, "Customer Satisfaction”, Oriento Press, 2004, 